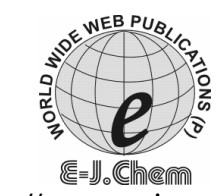

http://www.e-journals.net
ISSN: 0973-4945; CODEN ECJHAO

E-Journal of Chemistry

2008, 5(S1), 1037-1047

\title{
Synthesis of Calix[4]resorcinarene Based Dyes and its Application in Dyeing of Fibres
}

\author{
VINOD K JAIN*, SHIBU G PILLAI ${ }^{\dagger}$ and PARIN H. KANAIYA* \\ *Department of Chemistry, School of Sciences, \\ Gujarat University, Ahmedabad, India \\ Chemical Engineering Department, Institute of Technology, \\ Nirma University of Science and Technology, Ahmedabad, India. \\ drvkjain@hotmail.com
}

Received 24 April 2008; Accepted 20 June 2008

\begin{abstract}
Four new 'upper rim' azocalix[4]resorcinarene have been synthesized by coupling calix[4]resorcinarene with different diazotized aromatic compounds of sulphanilic acid, anthranilic acid, $o$-aminophenol, and $p$-aminobenzoic acid. The prepared compounds were characterized based on m.p., elemental analysis, FT-IR, ${ }^{1} \mathrm{H}-\mathrm{NMR}$. These dyes have been used for the dyeing of textile fibres like cotton and wool. Their fastness properties such as fastness to sunlight, water, washings, and perspiration have also been studied. The synthesized dyes have been employed for computerized colour strength determination through colour matching with known standards. Their $\mathrm{L}, \mathrm{A}^{*}, \mathrm{~B}^{*}$ values as well as the colour difference values such as $\Delta \mathrm{L}, \Delta \mathrm{A}^{*}, \Delta \mathrm{B}^{*}, \Delta \mathrm{C}$, and $\Delta \mathrm{H}$ have also been reported.
\end{abstract}

Keywords: Calix[4]resorcinarene, Upper rim, Azodyes, Fibres

\section{Introduction}

Dyes $^{1-3}$ and pigments are chemical components that are responsible for much of the colour in the natural world and which are added to manufactured goods such as textiles, and foodstuffs to generate a desired colour. Unlike pigments, dyes are soluble in the medium in which they are applied and hence are absorbed to a certain extent by the material. There have been very few reports wherein macrocycles such as crown ethers and calixarenes have been used as components for the preparation of azo dyes. Calix[n]arenas have been mostly reported as the coupling component for various diazotized aromatic amines ${ }^{4-6}$ while amino crown ether has been used as the diazo component ${ }^{7}$. 
Calix[4]resorcinarene ${ }^{8}$ are analogues of calixarenes, possessing two hydroxy groups on benzene rings at extra annular position forming a macrocycle. Calix[4]resorcinarene are synthesized by the acid-catalyzed cyclocondensation of resorcinol with various aliphatic or aromatic aldehydes $^{9-12}$. They have found application as macrocyclic receptor, as dendrimers in biological systems, nano-capsule, nano- particales, opticalchemosensors, supramolecular tectons, host molecules, as components in liquid crystals, photo resists, selective membranes, surface reforming agents, HPLC stationary phase, as ion channel mimics and metal ion extraction agents ${ }^{13-26}$. However, no work has been reported wherein derivatives of calix[4]resorcinarene have been used as the active coloring materials.

Hence, in the present work we are reporting four azocalix[4]resorcinarene derived from coupling of diazonium salt of sulphanilic acid, anthranilic acid, $o$-aminophenol, and $p$-aminobenzoic acid with calix[4]resorcinarene, with an aim of studying the dyeing potential of azocalix[4]resorcinarene on textile fibers like cotton and wool.

\section{Experimental}

\section{Chemicals and reagents}

All the chemicals used were of analytical reagent grade of BDH, E-Merck or Qualigens unless otherwise specified.

\section{Instrumentation}

Melting points were taken in a single capillary tube using a Veego melting point (Model: VMP-DS, India) apparatus and were uncorrected. Elemental analysis was carried out on Perkin Elmer, Series II, 2400 elemental analyzer. IR spectra were recorded on Bruker tensor 27 Infrared spectrophotometer as $\mathrm{KBr}$ pellets and expressed in $\mathrm{cm}^{-1}$. ${ }^{1} \mathrm{HNMR}$ spectra were recorded in DMSO- $\mathrm{d}_{6}$ on a Bruker ARX 500 instrument, using tetramethylsilane as internal standard. Electronic spectra were recorded on Jasco V-570 UV-visible spectrophotometer. The colour matching spectra were recorded on "Mac beth Colour Eye" spectrophotometer, with attached computer system.

\section{Synthesis}

Calix[4]resorcinarenes was synthesized as described by a previously reported method ${ }^{26,27}$.

Synthesis of calix[4]resorcinarene dyes (1-4)

Diazotization of the various amines was effected with $\mathrm{NaNO}_{2}$ and $\mathrm{HCl}$. A typical procedure is described below for Sulphanilic acid (I). Anthranilic acid based azocalix[4]resorcinarene (II), $o$-aminophenol based azocalix[4]resorcinarene (III), and $p$-amino benzoic acid based azocalix[4]resorcinarene (IV) were obtain using same method in $60-70 \%$ yield. The purified compound were obtained after column chromatography and then characterized.

Calix[4]resorcinarene-sulphanilic acid dye I(4-\{[4,6,10,12,16,18,22,24-octahydroxy2,8,14,20-tetramethyl-11,17,23-tris[(4-sulphophenyl) diazenyl]pentacyclo [19.3.1.1 ${ }^{3,7}$. $\left.1^{9,13} \cdot 1^{15,19}\right]$ octacosa-1(25),3,5,7(28),9,11,13(27),15,17,19(26),21,23-dodecaene-5-yl] diazenyll benzene sulphonic acid)

Sulphanilic acid $(1.43 \mathrm{~g}, 0.0083 \mathrm{M})$ and $2 \mathrm{~mL}$ conc. $\mathrm{HCl}$ were added to $15 \mathrm{~mL}$ of water and the resulting solution was cooled to $0^{0} \mathrm{C}$. Then a solution of $\mathrm{NaNO}_{2}(0.6 \mathrm{~g}, 0.0087 \mathrm{M})$ in 10 $\mathrm{mL}$ of water was added drop wise at such a rate to maintain the temperature below $5^{\circ} \mathrm{C}$. The resulting mixture was slowly added to a solution of calix[4]resorcinarene (1g, 0.0018 M) 
and sodium hydroxide $(0.8 \mathrm{~g}, 0.02 \mathrm{M})$ in $20 \mathrm{~mL}$ of water at $0-5^{\circ} \mathrm{C}$. The reaction mixture was stirred for $2-4 \mathrm{~h}$ at the same temperature, and the product was obtained by salting out with sodium chloride in $60-70 \%$ yield.

Dark brown powder; m.p. $>300^{\circ} \mathrm{C} ; \lambda_{\max } 425 \mathrm{~nm}$ in DMF; IR (KBr) $3431.73(-\mathrm{OH})$, $1598(-\mathrm{N}=\mathrm{N}-), 834(\mathrm{Ar}-\mathrm{S}) \mathrm{cm}^{-1} ;{ }^{1} \mathrm{H}$ NMR $\left(\mathrm{DMSO}_{6}\right) \delta 1.63 \mathrm{ppm}\left(\mathrm{d}, 12 \mathrm{H}, \mathrm{CHCH}_{3}\right), \delta 5.01$ ppm (q, 4H, $\left.\mathrm{CHCH}_{3}\right), \delta$ 7.48-8.03 ppm (m, ArH), $8.34(\mathrm{~s}, 12 \mathrm{H}, \mathrm{OH})$. Anal. calcd. for $\mathrm{C}_{56} \mathrm{H}_{48} \mathrm{O}_{20} \mathrm{~N}_{8} \mathrm{~S}_{4}$ : C, 52.49; H, 3.78; N, 8.75. Found: C, 52.40; H, 3.75; N, 8.70.

Calix[4] resorcinarene-anthranilic acid dye II (2-\{[11,17,23-tris[(2-carboxyphenyl) diazenyl]4,6,10,12,16,18,22,2 4-octahydroxy-2,8, 14,20-tetramethylpentacyclo $\left[19.3 \cdot 1 \cdot 1^{3,7} \cdot 1^{9,13} \cdot 1^{15,19}\right] \quad$ octacosa-1(25),3,5,7(28),9, 11,13(27), 15,17,19(26),21,23dodecaene-5-yl] diazenyl\}benzoic acid)

Brown powder; m.p. $>300^{\circ} \mathrm{C}$; $\lambda_{\max } 431 \mathrm{~nm}$ in DMF; IR $(\mathrm{KBr}) 3467.38(\mathrm{OH}), 1534.06$ $(-\mathrm{N}=\mathrm{N}-), 1631.48(\mathrm{C}=\mathrm{O}) \mathrm{cm}^{-1} ;{ }^{1} \mathrm{H}$ NMR $\left(\mathrm{DMSO}_{-} \mathrm{d}_{6}\right) \delta 1.65 \mathrm{ppm}\left(\mathrm{d}, 12 \mathrm{H}, \mathrm{CHCH}_{3}\right), \delta 4.98$ ppm (q, 4H, $\left.\mathrm{CHCH}_{3}\right), \delta$ 7.48-8.43 ppm (m, ArH), $8.92 \mathrm{ppm}(\mathrm{s}, 12 \mathrm{H}, \mathrm{OH})$. Anal. calcd. for $\mathrm{C}_{60} \mathrm{H}_{48} \mathrm{O}_{16} \mathrm{~N}_{8}:$ C, 63.38; H, 4.25; N, 9.85. Found: C, 63.32; H, 4.21; N, 9.79.

Calix[4]resorcinarene-o-aminophenol dye III 5,11, 17,23-tetrakis[(2-hydroxyphenyl) diazenyl]-2,8,14,20-tetra methyl-pentacyclo [19.3.1.1 $\left.1^{3,7} \cdot 1^{9,13} \cdot 1^{15,19}\right]$ octacosa-1(25),3,5, 7(28),9,11,13(27),15,17, 19(26),21,23-dodecaene-4,6,10,12,16,18,22,24-octol

Reddish brown powder; m.p.> $300^{\circ} \mathrm{C}$; $\lambda_{\max } 440 \mathrm{~nm}$ in DMF; IR (KBr) $3429.78(\mathrm{Ar}-\mathrm{OH})$, $1607.38(-\mathrm{N}=\mathrm{N}-) \mathrm{cm}^{-1} ;{ }^{1} \mathrm{H}$ NMR (DMSO-d $\left.{ }_{6}\right) \delta 1.65 \mathrm{ppm}\left(\mathrm{d}, 12 \mathrm{H}, \mathrm{CHCH}_{3}\right), \delta 4.88 \mathrm{ppm}(\mathrm{q}$, $\left.\mathrm{CHCH}_{3}\right), \delta$ 7.1-8.0 ppm (m, ArH), $\delta 10.12 \mathrm{ppm}(\mathrm{s}, 12 \mathrm{H} \mathrm{OH})$. Anal. calcd. for $\mathrm{C}_{56} \mathrm{H}_{48} \mathrm{O}_{12} \mathrm{~N}_{8}: \mathrm{C}$, 65.62; H, 4.72; N, 10.93. Found: C, 65.42; H, 4.71; N, 10.89 .

Calix [4] resorcinarene-p-aminobenzoicacid dye IV (4-\{[11,17,23-tris[(4-carboxy phenyl) diazenyl]4,6,10,12,16,18,22,24-octa hydroxy-2,8,14,20-tetramethyl pentacyclo $\left[19.3 \cdot 1 \cdot 1^{3,7} \cdot 1^{9,13} \cdot 1^{15,19}\right]$ octacosa-1 (25),3,5,7(28),9, 11,13(27),15,17, 19(26),21,23-dodecaene-5-yl] diazenyl\}benzoic acid)

Brown powder; m.p.> 300 ${ }^{\circ}$; $\lambda_{\max } 435 \mathrm{~nm}$ in DMF; IR (KBr) 3410.49 (Ar-OH), 1517.02 $(-\mathrm{N}=\mathrm{N}-), 1637.27 \mathrm{~cm}^{-1} ;{ }^{1} \mathrm{H}$ NMR (DMSO-d 6$) \delta 1.65 \mathrm{ppm}(\mathrm{d}, 12 \mathrm{H} \mathrm{CHCH}$ ), $\delta 4.96 \mathrm{ppm}$ $\left(\mathrm{q}, 4 \mathrm{H}, \mathrm{CHCH}_{3}\right), \delta$ 7.8-8.5 ppm $(\mathrm{m}, \mathrm{ArH}), 9.02 \mathrm{ppm}(\mathrm{s}, 12 \mathrm{H}, \mathrm{OH})$. Anal. calcd. for $\mathrm{C}_{60} \mathrm{H}_{48} \mathrm{O}_{16} \mathrm{~N}_{8}$ : C, 63.38; H, 4.25; N, 9.85. Found: C, 63.32; H, 4.21; N, 9.79.

\section{Fastness studies and colour matching of dye samples}

\section{Scouring of fibres}

$2.0 \mathrm{~g}$ Caustic soda and $2.0 \mathrm{~g}$ common detergent in $200 \mathrm{~mL}$ water were mixed and $3.5 \mathrm{~g}$ fibres hanks were added. The mixture was boiled for $3 \mathrm{~h}$, and then cooled and the hank was washed thoroughly with water to remove the adhered caustic soda and detergent completely.

Dyeing of fibres

$0.25 \mathrm{~g}$ Calix[4]resorcinarene dyes was added in $35 \mathrm{~mL}$ water and the solution was heated to $50^{\circ} \mathrm{C}$. The scoured $3.5 \mathrm{~g}$ fibres hanks were then added and the dyeing bath was maintained at $90^{\circ} \mathrm{C}$ for $30 \mathrm{~min}$. It was then cooled to room temperature and $1.0 \mathrm{~g}$ of common salt was added. The dyed hanks were then removed and rinsed with cold water and dried. 


\section{Fastness to water}

Dyed and undyed specimens were immersed in water for $30 \mathrm{~min}$, drained, and placed in a perspirometer. The change in colour of the dyed cloth and the staining of the undyed cloths are assessed be means of the standard grey scale.

\section{Fastness of washing}

The test specimen was cut into two parts. One part along with undyed cotton or wool was then added to $0.5 \%$ common detergent solution in water at $40^{\circ} \mathrm{C}-45^{\circ} \mathrm{C}$. The solution was agitated for $30 \mathrm{~min}$. The specimen was removed, rinsed with water, and then dried by pressing with iron. Change in colour of the dyed specimen and degree of staining of the undyed specimen was assessed by standard gray scale.

\section{Fastness to perspiration}

Since human perspiration can be acidic or alkaline, both acid and alkaline solutions have to be used for the test. The acidic condition is simulated by preparing a solution containing $10 \mathrm{~g}$ sodium chloride, $1.0 \mathrm{~g}$ disodium hydrogen phosphate, and $1.0 \mathrm{~g}$ lactic acid per liter. The alkaline condition is provided by a solution containing $10 \mathrm{~g}$ sodium chloride, $1.0 \mathrm{~g}$ disodium hydrogen phosphate, and $4.0 \mathrm{~g}$ ammonium carbonate per liter. The tests were carried out in dry atmosphere at $38-40^{\circ} \mathrm{C}$ in glass test tubes. The test specimen was made up by taking a piece of the dyed knitted yarn and rolled with the undyed knitted yarn in such a way that the roll just fits the bore of the test tube. The test specimen were thoroughly wetted with the acid solution and then inserted in different glass test tube, so that one-third of the roll projects outside. The four tests correspond to grades 1 to 4 and differ only in the time of treatment i.e. $40 \mathrm{~min}, 2,6$ and $16 \mathrm{~h}$. The change in colour of the dyed yarn and the degree of staining of the undyed yarn is assessed visually. A similar test is performed with the alkaline solution also.

\section{Fastness to light}

The dyed specimen along with standard was exposed to xenotest in which half of the dyed material was kept unexposed to light. The system was allowed to stand in the light for $10 \mathrm{~h}$. The specimen was then taken away and the exposed site was compared with unexposed site along with standards.

\section{Colour matching of dye samples}

The colour and percentage strength of the dye samples were evaluated by matching reflectance measurements (colour matching system) ${ }^{28}$. A chromaticity curve was obtained, and with the help of the computer, their L, A, B values and colour difference values such as $\Delta \mathrm{L}, \Delta \mathrm{A}, \Delta \mathrm{B}, \Delta \mathrm{C}, \Delta \mathrm{H}$, the total colour and the percentage strength were evaluated.

\section{Results and Discussion}

\section{Synthesis and characterizations}

In this work, 4 new azo compounds were synthesized by coupling of diazonium salt of sulphanilic acid, anthranilic acid, $o$-aminophenol, and $p$-aminobenzoic acid with calix[4]resorcinarene. These compounds (I-IV) are shown in scheme 1, were obtained in quantitative yield.

These compounds were characterized using FT-IR, ${ }^{1} \mathrm{HNMR}$, and elemental analysis. 
The FT - IR Spectra of all compound I-IV showed a weak band within the range 3500$3400 \mathrm{~cm}^{-1}$ corresponding to $-\mathrm{OH}$, while the other stretching vibration of the $\mathrm{N}=\mathrm{N}$ group in the range1610-1515 $\mathrm{cm}^{-1}$ was masked by the intense bands due to ring vibration.

The ${ }^{1} \mathrm{H}-\mathrm{NMR}$ (DMSO- $\mathrm{d}_{6}$ ) spectrum showed a doublet at $1.65 \mathrm{ppm}$ for $\left(-\mathrm{CH}_{3}\right)$, a quartert at 5.0-4.8 ppm for (-CH), a multiplet from 7.0-8.5 ppm for aromatic protons $(\mathrm{ArH})$, a singlet at 8.3-10.2 ppm for $(-\mathrm{OH})$.

\section{Dyeing of fibres}

The structural and physical properties of the calix[4]resorcinarene-dyes I to IV , reveals that they may be classified as "Direct dyes" for the dyeing of cotton and wool fibres. Direct dyes are often known as "Salt dyes" since common salt or glauber's salt is generally added to the dye for exhaustion. It is generally seen that direct dyes on cotton, have poor fastness to washing and light, however the washing and light fastness can be somewhat improved by various after-treatments on the fibres ${ }^{29}$.

All after-treatment processes increases the expenditure, time, labor, material, and makes the process disadvantageous over other dyeing process, i.e., vat dye, mordant dye, azoic dye etc. It has been seen that the synthesized calix[4]resorcinarene-dyes I to IV, have good fastness towards washing and light for dyeing cotton and wool fibres without the use of any after-treatment method.

\section{Effect of dyestuff concentrations}

The behaviour of varying dye concentration was studied on the dyeing of the fibre. The results (Figure 1) showed that with the increase in dye concentration from 0.2 to $0.4 \%$ there was an increase in reflectance on the fibres, which suggest the greater availability of dyestuff in solution and its penetration into the fibrous material ${ }^{30}$.

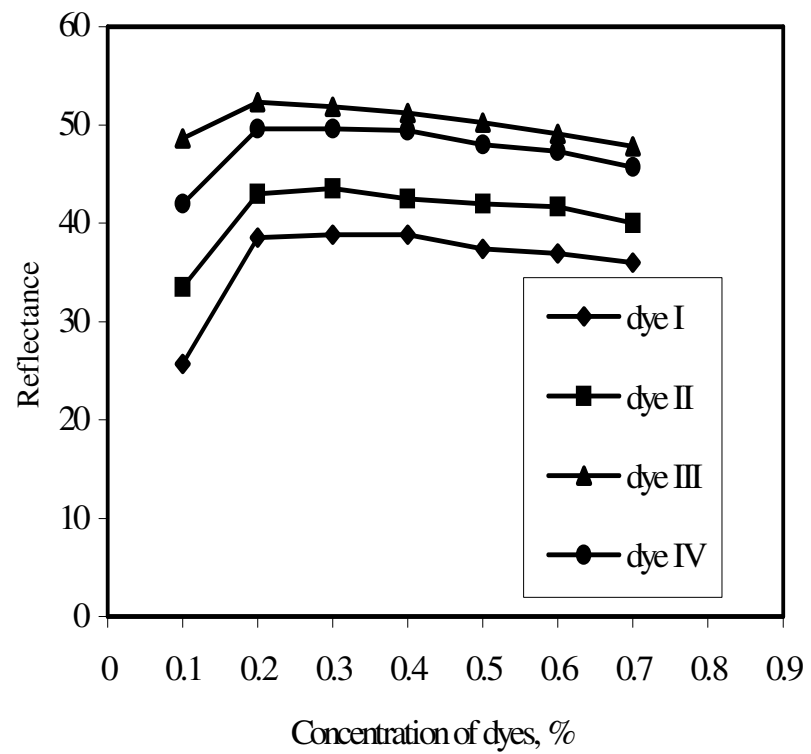

Figure 1. Effect of concentration of dyes on fibres 


\section{Effect of salt concentration}

The effect of varying the concentration of salt (1.0 to 5.0\%) was assessed for the dyed fabrics. The results showed that 3.0 to $5.0 \%$ concentration of salt did not have much effect on the reflectance intensity of the fibre (Figure 2).

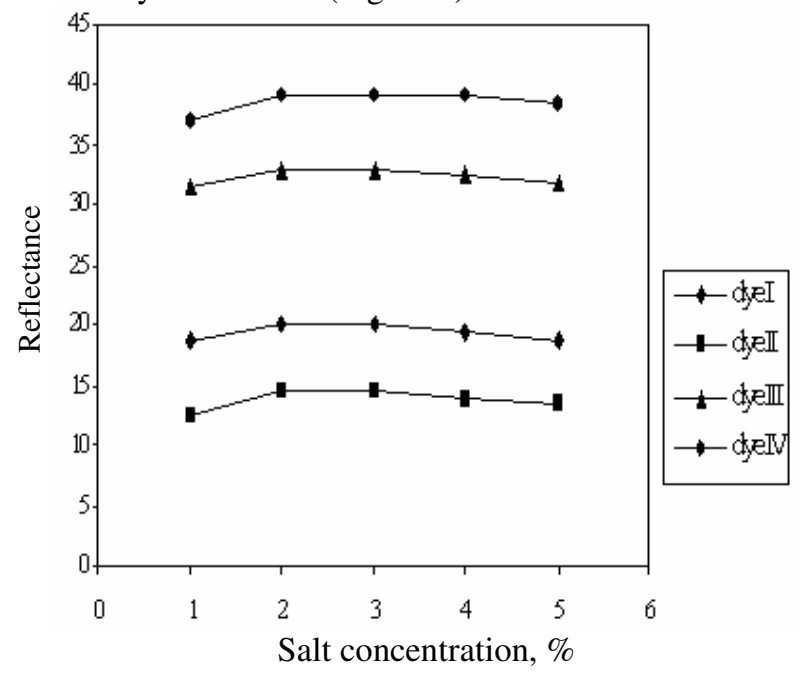

\section{Effect of $p H$}

Figure 2. Effect of salt concentration on the dyed fibres

The cotton fibres were dyed at various $\mathrm{pH}$ between 3-10.5 and its effect was studied by the reflectance measurements. The data showed (Figure 3) that at a lower $\mathrm{pH}$ the dyeing was incomplete, however, the maximum reflectance value was achieved between $\mathrm{pH} 6.5$ and 8 but beyond $\mathrm{pH} 8$, the dyeing capacity decreased gradually.

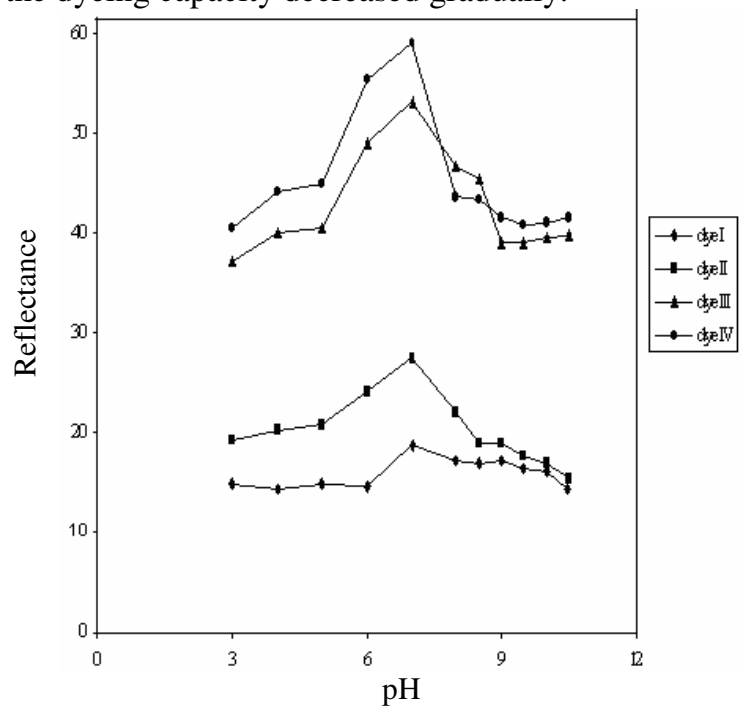

Figure 3. Effect of $\mathrm{pH}$ on the dyed fibres 


\section{Fastness studies}

Fastness to all other agencies e.g. washing, perspiration etc. is assessed on scale of 5 . The change in colour is assessed by visual examination, with reference to five pairs of grey dyed cloths, each pair representing a visual difference and contrast.

The light fastness of dyeing on the cotton was of the level 5-6. For other fastness tests, a specimen of dyed fabric was kept in intimate contact with an undyed specimen of the same or a different fabric and was subjected on the laboratory test. In all cases the change in colour of the dyed specimen and the staining of the undyed textile was assessed visually using the standard grey scale. The results show that fastness to water, washing, acidic, and alkaline perspiration were at the level 3-5, indicating very slight alteration in the shade or lose in depth of the dye. Same, in the case of staining this was of level 3 to 5 as shown in Table 1 Therefore, the calix[4]resorcinarene-dyes could be considered as good candidate for dyeing cotton and wool fibres, due to their easy process of dyeing and normal to high value of fastness.

Table I. Fastness of the Synthesized Dyes on Cotton and Wool Fibres

\begin{tabular}{cccccccccccccc}
\hline \multirow{2}{*}{$\begin{array}{c}\text { Calix[4]resorcinarene- } \\
\text { dyes }\end{array}$} & \multicolumn{3}{c}{ Water } & \multicolumn{4}{c}{ Washing } & \multicolumn{4}{c}{$\begin{array}{c}\text { Acid } \\
\text { Perspiration }\end{array}$} & $\begin{array}{c}\text { Alkaline } \\
\text { Perspiration }\end{array}$ & $\begin{array}{c}\text { Light } \\
\text { Fastness }\end{array}$ \\
\cline { 2 - 14 } & a & b & c & a & b & c & a & b & c & a & b & c & \\
\hline I & 4 & 4 & 4 & 4 & $3-4$ & 4 & 4 & 4 & 4 & 4 & 4 & 4 & 5 \\
II & 4 & 4 & 4 & 4 & $3-4$ & 4 & 4 & 4 & 4 & 4 & 4 & 4 & 5 \\
III & 4 & $4-5$ & $4-5$ & 4 & 4 & 4 & 4 & $4-5$ & $4-5$ & 4 & $4-5$ & $4-5$ & $5-6$ \\
IV & 4 & 4 & $4-5$ & 4 & 4 & $4-5$ & 4 & $4-5$ & 4 & 4 & $4-5$ & $4-5$ & $5-6$ \\
\hline
\end{tabular}

a: Alteration in shade of dyed fabric; 5 to 1 : Shade unaltered to shade very much altered.

$b$ : Degree of staining cotton; 5 to 1 : No staining to very deep staining of adjacent white.

$c$ : Degree of staining wool; 5 to 1 : No staining to very deep staining of adjacent white.

Light fastness is assessed in the scale of 8 to 1: Best to Poor.

\section{Computerized colour matching}

The samples were evaluated with the 'Mac beth Colour Eye' computer colour matching system with illuminants $\mathrm{D}_{65}$ with $10^{\circ}$ observer. The results on colour coordinates of the samples are given in Table 2, 3. Taking the various reactive dyes as standard, the reflectance measurements were made. The standard was selected on the basis of maximum match shade with the synthesized dyes. It should not be difficult to visualize the appearance of shade and draw some meaningful interference from the $\mathrm{L}, \mathrm{C}$ and $\mathrm{H}$ specification of the colour. The hue angle tells us about the colour itself i.e. whether the colour is yellow, green, red, purple, or blue. The chroma tells us about the purity of the colour, while the colour (light or dark) is reflected by the value L. The results showed that $\Delta \mathrm{L}$ value were negative for dye I and III on cotton fibre and dye I and II on wool fibre, which suggests that these compounds are darker then the standard taken against them. The chroma value $(\Delta \mathrm{C})$ was negative for all except dye II on cotton fibre as well as wool fibre, with duller effect, which suggests the leasing effect of these dyes

It can be further seen how $\mathrm{L}, \mathrm{A}, \mathrm{B}, \mathrm{C}, \mathrm{H}$ colour specifications are able to define any colour in a meaningful manner, which is very easy to understand, compared to the trichromatic coordinate. 
Table 2. Colour Coordinate values for calix[4]resorcinarene-dyes on cotton fibre

\begin{tabular}{ccccccccccccc}
\hline $\begin{array}{c}\text { Compd. } \\
\text { No. }\end{array}$ & $\mathrm{L}^{*}$ & $\mathrm{~A} *$ & $\mathrm{~A} *$ & $\mathrm{C} *$ & $\mathrm{H}$ & $\Delta \mathrm{L}$ & $\Delta \mathrm{A}$ & $\Delta \mathrm{B}$ & $\Delta \mathrm{C}$ & $\Delta \mathrm{H}$ & $\Delta \mathrm{E}$ & $\%$ strength \\
\hline I & 73.30 & 4.19 & 22.135 & 22.528 & 79.249 & -0.056 & -0.127 & -0.14 & -0.161 & 0.098 & 0.197 & 100.23 \\
& $(73.356)$ & $(4.317)$ & $(22.275)$ & $(22.689)$ & $(79.00)$ & & & & & & & \\
II & 52.794 & 25.495 & 49.401 & 55.592 & 62.677 & 0.060 & 0.079 & 0.175 & 0.192 & 0.010 & 0.201 & 98.74 \\
& $(52.734)$ & $(25.416)$ & $(49.226)$ & $(55.40)$ & $(62.667)$ & & & & & & & \\
III & 67.776 & 8.739 & 29.655 & 30.916 & 73.551 & -0.018 & 0.028 & -0.074 & -0.063 & - & 0.081 & 99.86 \\
& $(67.794)$ & $(8.711)$ & $(29.729)$ & $(30.979)$ & $(73.639)$ & & & & & 0.048 & & \\
IV & 60.057 & 10.137 & 19.909 & 22.341 & 62.991 & 0.046 & -0.210 & -0.088 & -0.018 & 0.227 & 0.232 & 99.85 \\
& $(60.011)$ & $(10.347)$ & $(19.820)$ & $(22.359)$ & $(62.409)$ & & & & & & & \\
\hline
\end{tabular}

Table 3. Colour coordinate values for calix[4]resorcinarene-dyes on wool fibre

\begin{tabular}{ccccccccccccc}
\hline $\begin{array}{c}\text { Compd. } \\
\text { No. }\end{array}$ & $\mathrm{L}^{*}$ & $\mathrm{~A}^{*}$ & $\mathrm{~B} *$ & $\mathrm{C}^{*}$ & $\mathrm{H}$ & $\Delta \mathrm{L}$ & $\Delta \mathrm{A}$ & $\Delta \mathrm{B}$ & $\Delta \mathrm{C}$ & $\Delta \mathrm{H}$ & $\Delta \mathrm{E}$ & $\begin{array}{c}\% \\
\text { strength }\end{array}$ \\
\hline I & 73.128 & 4.224 & 22.22 & 22.618 & 79.205 & -0.2208 & -0.093 & -0.055 & -0.072 & 0.081 & 0.252 & 98.67 \\
& $(73.356)$ & $(4.317)$ & $(22.275)$ & $\begin{array}{c}(22.689) \\
(79.00)\end{array}$ & & & & & & & \\
II & 52.362 & 25.616 & 49.343 & 55.596 & 62.539 & -0.372 & 0.200 & 0.117 & 0.196 & -0.124 & 0.434 & 95.58 \\
& $(52.734)$ & $(25.416)$ & $(49.226)$ & $(55.40)$ & $(62.667)$ & & & & & & & \\
III & 68.092 & 8.645 & 29.523 & 30.763 & 73.649 & 0.298 & -0.066 & -0.206 & -0.216 & 0.005 & 0.368 & 102.5 \\
& $(67.794)$ & $(8.711)$ & $(29.729)$ & $(30.979)$ & $(73.639)$ & & & & & & & \\
IV & 60.283 & 10.096 & 19.871 & 22.289 & 63.041 & 0.272 & -0.251 & 0.050 & -0.070 & 0.246 & 0.373 & 101.501 \\
\hline
\end{tabular}




\section{Conclusion}

Diazo-coupling reactions are shown in Scheme 1. This pathway is the most convenient to give the best yield of diazo-coupling calixresorcinarene compound. We studied the diazocoupling reaction of calix[4]resorcinarene with sulphanilic acid, anthranilic acid, $o$-aminophenol, and $p$-aminobenzoic acid

The newly synthesized calix[4]resorcinarene based azo dyes were studied for their fastness towards various agencies like light, washing, perspiration etc on cotton and wool fibres. These dyes have shown good fastness properties and the dyeing process was found to be easy, requiring no after treatment processes. Further studies are underway to explore the complexation properties of these dyes with transition metal ions and rare earths in solution as well as in solid state.<smiles>[R]c1ccc(N)c([R])c1</smiles>

$$
\underset{0-5^{\circ} \mathrm{C}}{\stackrel{\mathrm{NaNO}_{2}+\mathrm{HCl}}{\longrightarrow}}
$$<smiles></smiles>

\section{Amino Derivative}

$$
\begin{array}{ll}
\text { I) } \mathrm{R}_{1}=\mathrm{H} ; & \mathrm{R}_{2}=\mathrm{SO}_{3} \mathrm{H} \\
\text { II) } \mathrm{R}_{1}=\mathrm{COOH} ; \mathrm{R}_{2}=\mathrm{H} \\
\text { III) } \mathrm{R}_{1}=\mathrm{OH} ; & \mathrm{R}_{2}=\mathrm{H} \\
\text { IV) } \mathrm{R}_{1}=\mathrm{H} ; & \mathrm{R}_{2}=\mathrm{COOH}
\end{array}
$$

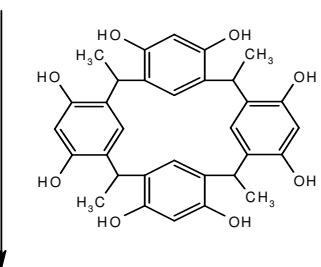

Dye I calix[4]resorcinarene-sulphanilic acid dye Dye II calix[4]resorcinarene-anthranilic acid dye Dye III calix[4]resorcinarene-o-am inophenol dye Dye IV calix[4]resorcinarene- $p$-am inobenzoic acid dye

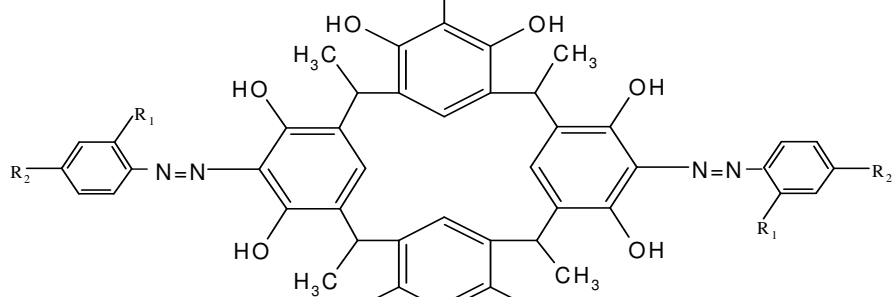

calix[4]resorcinarene-dyes

Scheme 1. Synthetic route for calyx[4]resorcinarene -dyes 


\section{Acknowledgements}

The authors gratefully acknowledge the financial assistance provided by Council of Scientific and Industrial Research (CSIR), New Delhi to carry out this work. The authors acknowledge CDRI (Lucknow), CSMCIR (Bhavanagar) for providing instrumental facilities and authors also acknowledge INFLIBNET, Ahmedabad for e-journals.

\section{References}

1. Venkataraman K, The Chemistry of Synthetic Dyes, Vol.-I, \& II, Academic Press, New York, 1952.

2. Abrahat E N, Dyes and their Intermediate, Edward Arnold Ltd., London, 1977.

3. Ferreira E S B, Hulme A N, McNab H and Quys A, Chem Soc Rev., 2004, 33, 329.

4. $\quad$ Karci F, Senner I and Deligoz H, Dyes Pigments, 2004, 59, 53.

5. $\quad$ Senner I, Karci F, Kilic E and Deligoz H, Dyes Pigments, 2004, 62,141.

6. $\quad$ Senner I, Karci F, Kilic E and Deligoz H, Dyes Pigments, 2004, 62, 149.

7. Agrawal Y K and Pandya B R, Dyes Pigments, 2002, 52, 161.

8. Timmerman P, Verboom W and Reinhoudt D N, Tetrahedron, 1996, 52, 2603.

9. Benedetti E, Pedon C, Iacovino R, Botta B, DelleMonach G, De Rosa M C, Botta M, Corelli F, Taft A and Santini A, J Chem Research (s), 1994, 476.

10. Botta B, Iacomacci P, Di Giovanni C, Delle Monach G, Gacs-Baitz E, Botta M, Taft A, Corelli F and Misti D, J Org Chem., 1992, 57, 3259.

11. Hedidi M, Hamdi S M, Mazari T, Boutemeur B, Rabia C, Chemat F and Hamdi M, Tetrahedron, 2006, 62, 5652.

12. Thoden Van Velzen E U, Engbersen J F J and Reinhoudt D N, J Am Chem Soc., 1994, 116, 3597.

13. Botta B, Cassani M, Acquarica I D, Misti D, Subissati D and Delle Monach G, Current Org Chem., 2005, 9(4), 337-355.

14. (a) Ge Y, and Yan C, J Chem Research, 2004, 279-281. (b) Boas U and Heegaard P M H, Chem Soc Rev., 2004, 33, 43-63.

15. Heaven M W, Raston C L and Atwood J L, Chem Commun., 2005, 892-894.

16. Gualbert J, Shahgaldian P, Lazar A and Coleman A W, J Incl Phenom Macrocycl Chem., 2004, 48, 37-44.

17. Thomas W and Bell Nicholas M H, Chem Soc Rev., 2004, 33, 589-98.

18. (a) MacGillivray L R and Atwood J L, J Solid State Chem., 2000, 152, 199.

(b) MacGillivray L R, Diamente P R, Reid J L and Ripmeester J P, Chem Commun 2000,359. (c) Harrison N K, Delley and Nazarenko AY, Chem Commun., 2000, 1387.

19. (a) Martinez G M, Teran C R, Tlapanco O P, Toscano A, Cruz-Almanza A, Fullerene Sci Tech., 2000, 8, 475 (b)F.C. Tucci, A.R.Renslo, D.M.Rudkevich and Rebek J, Angew Chem Int Ed., 2000, 30, 1076.

20. Yonetake K, Nakayama T and Ueda M, J Mater Chem., 2001, 11, 761.

21. (a) Ito H, Nakayama T and Ueda M, US Pat US 6093517 2000. (b) Haba O, Haga M, Ueda M, Morikawa O and Konishi H, Chem Mater., 1999, 11, 427. (c) Nakayama T, Takhashi D, Takeshi K and Ueda M, J Photopolym Sci Tech., $1999,12,347$. 
22. (a) Tbeur N, Rhlalou T, Hlaibi M, Langevin D, Metayerand M and Verchere J F, Carbohydr Res., 2000, 329, 409. (b) Pietraszkiewicz O, Kozbial M and Pietraszkiewicz M, Pol J Chem., 1998, 72, 886.

23. Ichimura K, Kurita E and Ueda M, Eur Pat EP 6712201995.

24. Pietraszkiewicz O and Pietraszkiewicz M, J Incl Phenom Macrocycl Chem.,1999, 35, 261.

25. Yoshino N, Satake A and Kobuke Y, Angew Chem Int Ed., 2001, 40, 457.

26. (a) Jain V K, Pillai S G and Kanaiya P H, J Braz Chem Soc., 2006, 17, 1316. (b) Jain V K, Pillai S G, Pandya R A, Agrawal Y K and Shrivastav P S, Anal Sci, 2005, 21, 129. (c) Jain V K, Pillai S G, Pandya R A, Agrawal Y K, Shrivastav P S, Talanta, 2005, 2, 466.

27. (a) Hogberg A G S, J Org Chem 1980, 45, 4498. (b) Timmerman P, Verboom W, and D N Reinhoudt, Tetrahedron, 1996, 52, 2603.

28. Patwardhan S, Instrumental Colour Matching for Textiles, Wool Research Association, Bombay, 1977.

29. Farbenindustrie Aktiengesellschaft I G, Manual for the Dyeing of Cotton and Other Vegetable Fibres, Frankfurt, 1936.

30. Sadov F, Korohagin M and Mateksy A, Chemicl Technology of Fibrous Materials, Mir Publishers, Moscow, 1978. 


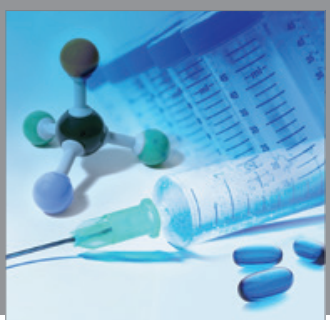

International Journal of

Medicinal Chemistry

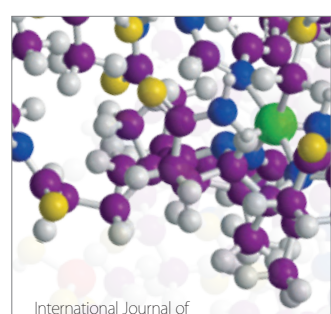

Carbohydrate Chemistry

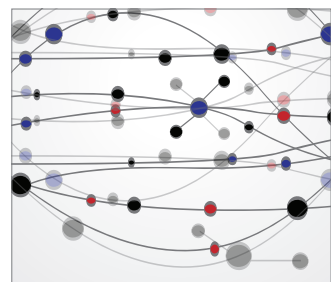

The Scientific World Journal
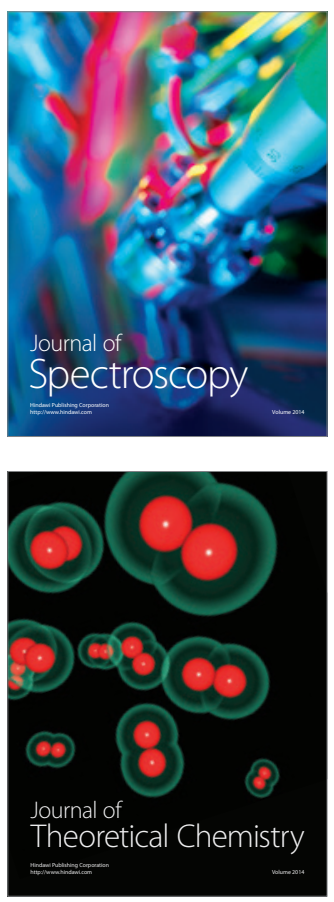
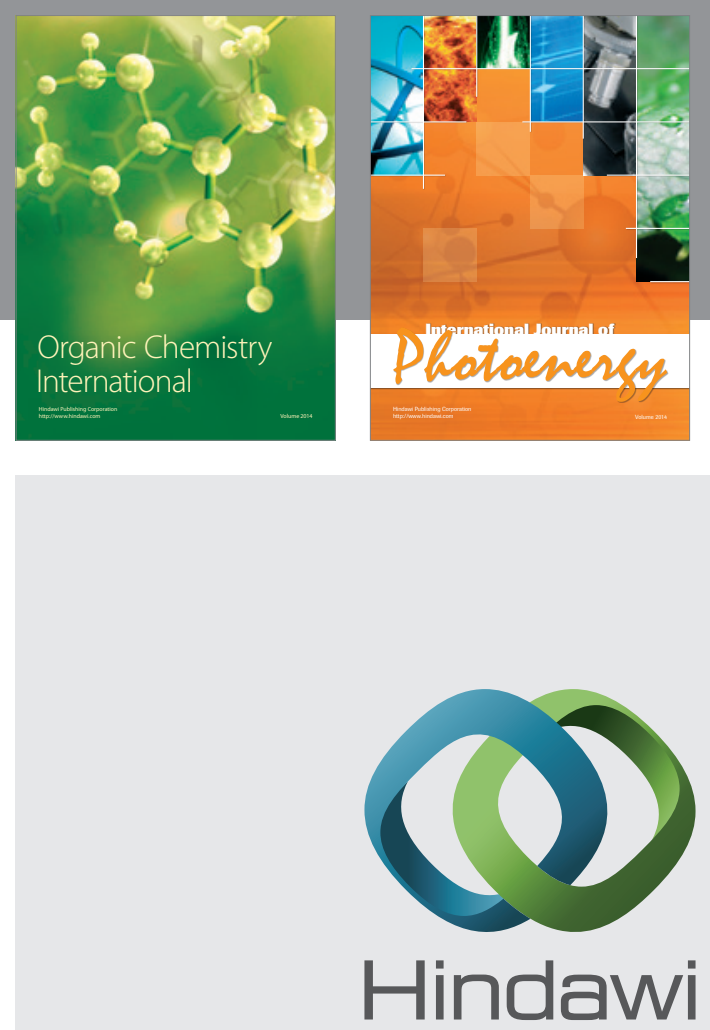

Submit your manuscripts at

http://www.hindawi.com
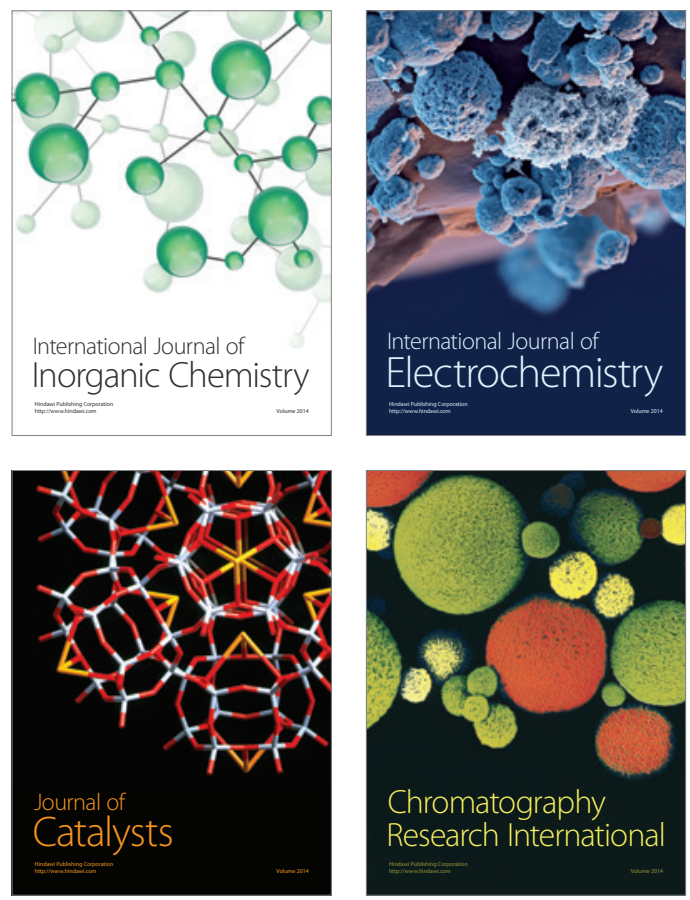
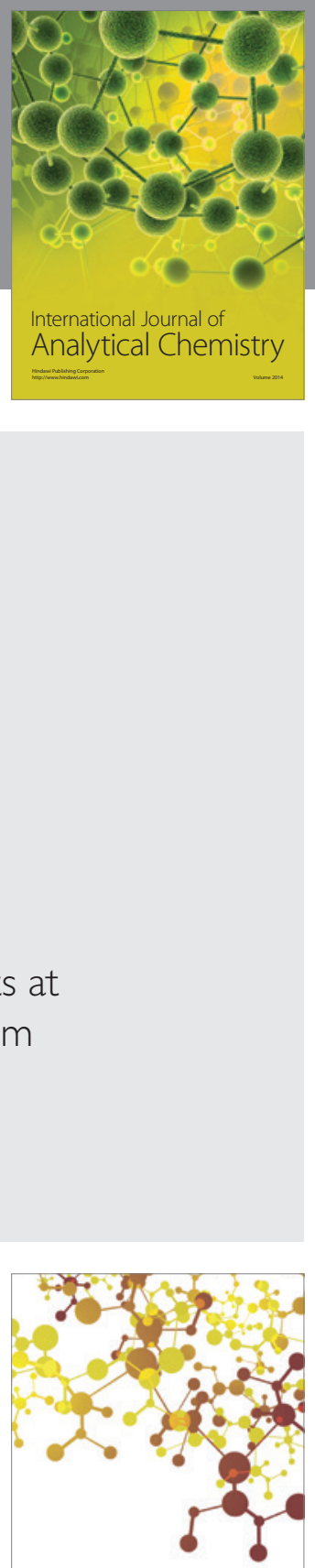

Journal of

Applied Chemistry
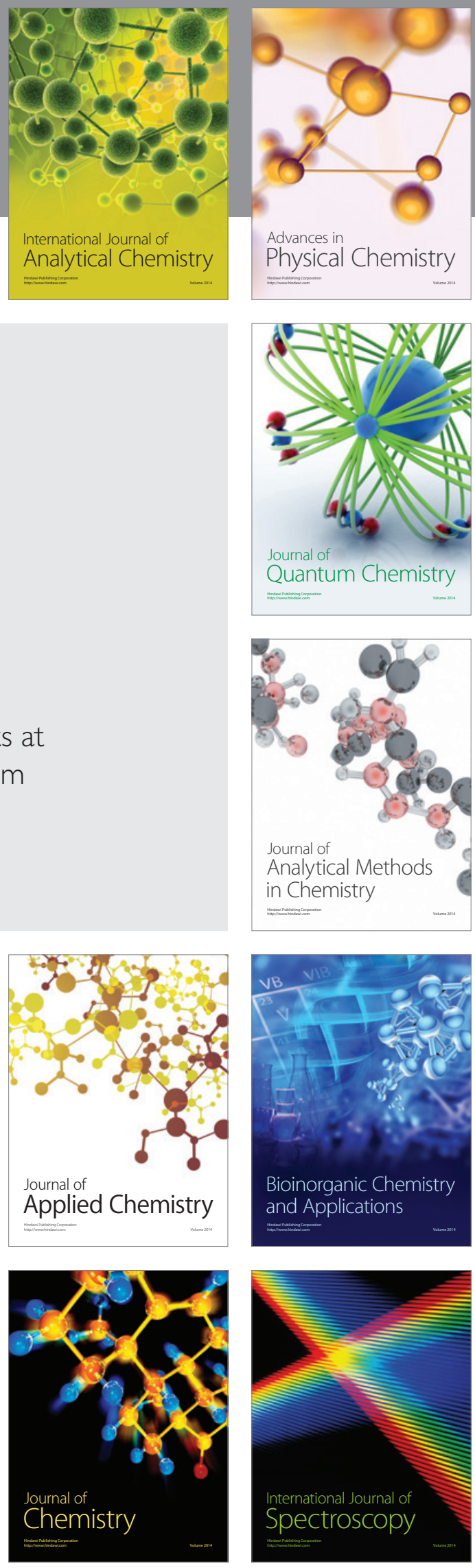